ISSN: 2224-0616

Int. J . Agril. Res. Innov. Tech. 8 (2): 47-53, December 2018

DOI: https:// doi.org/ 10.3329/ijarit.v8i2.40555

Available online at https://ijarit.webs.com

https:// www.banglajol.info/index.php/ IJ ARIT

\title{
ROLE OF MICRO AND MACRONUTRIENTS ENRICH FERTILIZERS ON THE GROWTH PERFORMANCE OF PRAWN (Macrobrachium rosenbergii), ROHU (Labeo rohita) AND MOLA (Amblypharyngodon mola) IN A POLYCULTURE SYSTEM
}

\author{
M.M. Rahman', S. Sultana2*, M. Kabiraj ${ }^{1}$ and M. Das ${ }^{3}$
}

Received 30 October 2018, Revised 12 December 2018, Accepted 26 December 2018, Published online 31 December 2018

\begin{abstract}
A six month's experiment was carried out in earthen ponds to evaluate the effect of micro and macro nutrients on the growth performance of Prawn (Macrobrachium rosenbergii), Rohu (Labeo rohita) and Mola (Amblypharyngodon mola) in a polyculture system during July to December 2017. The trial was conducted into two different treatments and one control each with three replications. In treatment-1, macronutrients enrich fertilizers like urea, TSP and molasses-yeast mixture were applied at the rate of $2.45,2.45$, and $3.09\left(\mathrm{~g} \mathrm{~m}^{-2}\right.$ week ${ }^{1}$ ), whereas in treatment- 2 micronutrients composition mixer applied at the rate of $4.50 \mathrm{~g} \mathrm{~m}^{-2}$ week $^{-1}$ while no micro and macronutrients were applied in control. The mean value of all water quality parameters showed no significant differences among control and two treatments when One-way ANOVA was performed except hardness. The average final mean individual weights of prawn, rohu and mola in control, treatment- 1 and treatment-2 were 22.10, 24.35, and $24.70 \mathrm{~g} ; 141.10,190.60$ and $182.20 \mathrm{~g} ; 3.36,3.67$ and $3.73 \mathrm{~g}$, respectively. The survival rates of various species namely prawn, rohu and mola in control, treatment-1 and treatment- 2 were $73.33,89.58$ and $86.25 \%$; 78.00, 74.00 and $74.00 \%$; 10.67, 15.33 and $15.33 \%$, respectively. There was no significant difference in the survival rates of prawn, rohu and mola among control and treatments. Production after six months of culture was $351.8,461.5$ and $445.3 \mathrm{~kg} \mathrm{ha}^{-1}$ in control, treatment- 1 and treatment-2, respectively which were significantly different at $5 \%$ level of significance.
\end{abstract}

Keywords: Micronutrient, Macronutrient, Polyculture, Growth, Production

\footnotetext{
${ }^{1}$ Fisheries and Marine Resource Technology Discipline, Khulna University, Khulna - 9208, Bangladesh.

${ }^{2}$ Assistant Professor, Fisheries and Marine Resource Technology Discipline, Khulna University, Khulna - 9208, Bangladesh

${ }^{3}$ Assistant Professor, Department of Aquaculture, Faculty of Fisheries, Bangabandhu Sheikh Mujibur Rahman Agricultural University, Gazipur-1706, Bangladesh

*Corresponding author's email: shamimasultana87@gmail.com (Shamima Sultana)
}

Cite this article as: Rahman, M.M., Sultana, S., Kabiraj, M. and Das, M. (2018). Role of micro and macronutrients enrich fertilizers on the growth performance of prawn (Macrobrachium rosenbergii), rohu (Labeo rohita) and mola (Amblypharyngodon mola) in a polyculture system. Int. J. Agril. Res. Innov. Tech.. 8(2), 47-53.

\section{Introduction}

Bangladesh is blessed with huge water resources with a wide range of aquatic diversity. This country is one of the world's leading fish producing countries with a total production of 41.34 lakh MT, where aquaculture contributes 56.44 percent to total production and ranked $5^{\text {th }}$ in world aquaculture product (FAO, 2016). Moreover, this country has achieved selfsufficiency in fish production. Still Government is trying to sustain this growth performance. As we know that, the polyculture is particularly ideal in developing countries due to certain options such as management and investments. It is now the most common practice of carp culture and several species combinations (Hoq et al., 1996). Mola (Amblypharyngodon mola) is a micronutrient- rich small fish that is very popular, and grows well along with carps in ponds. The concept of prawn (M. rosenbergii), rohu (L. rohita) and mola (A. mola) polyculture rests on the idea that when compatible species of different feeding habits are cultured in the same ponds, the maximum utilization of all the fish food of different column of the ponds is established. On the other hand, it is widely recommended that biological productivity in aquaculture ponds is limited by nutrients. Actually optimizing production in pond fish culture by the use of fertilizers is an important task as plankton is the basic food of all the organisms living in the water and fishes and other aquatic organisms depend on this basic food directly and indirectly (Moses, 
1983; Westly, 1984). The quantity of nutrients in a pond plays a major role in determining the amount and quality of plankton (Debeljak et al., 1990; Harris, 1986; Pearson et al., 1984). Actually, pond fertilization enhances the growth of primary producers, which are consumed by fish, ultimately augmenting the fish crop. Inorganic fertilizers are more readily soluble and have immediate effect on plankton growth. Although a number of studies have been conducted on the effects of inorganic macro fertilizers like nitrogen and phosphorus in carp polyculture (Wahab et al., 1994) and benefits of using macro nutrient enrich fertilizer in aquaculture is well established (Chakrabarty et al., 1976; Green et al., 1989, Boyd, 1982; Boyd 1976), no studies on the evaluation of micronutrient enrich fertilizer effectiveness on plankton was found to be conducted in our country. In accordance with Green et al. (1992), application of macro and micronutrients enrich fertilizers in fish ponds results higher fish production than from natural unfertilized systems. Phytoplankton need numerous other trace metals (micronutrients) required for the activity of key enzymes and other intracellular functions to grow (Hassler et al., 2012). The main purpose of pond fertilization is to augment the production of plankton, which serves as natural food of the fishes; because fertilization stimulates both the autotrophic and heterotrophic levels which increase fish production (Garg and Bhatnagar, 1999). The macro and micronutrient enrich fertilizer can be an effective tool to enhance the production of prawn (M. rosenbergii), rohu (L. rohita) and mola (A. mola) in polyculture system. Therefore, the aim of the proposed research was to find out the role of micro and macronutrients enrich fertilizer in the production of prawn, rohu and mola polyculture system.

\section{Materials and Methods}

\section{Study area and period}

The study was conducted from the experimental pond complex II at Fisheries and Marine Resource Technology Discipline of Khulna University, Khulna in Bangladesh during J uly to December, 2017. All ponds were rectangular in shape with a maximum depth of $1.5 \mathrm{~m}$. All the ponds were fully exposed to prevailing sunlight.

\section{Experimental Design}

The trial was conducted into two different treatments and one control with three replications each. Stocking density of prawn (M. rosenbergii), rohu (L. rohita) and mola (A. mola) were same in all treatments shown in the Table 1. In treatment $T_{1}$, macro nutrients like urea, TSP and Molasses-yeast mixture were applied at the rate of 2.45, 2.45, and $3.09\left(\mathrm{~g} \mathrm{~m}^{-2}\right.$ week $\left.{ }^{-1}\right)$, and micro nutrients composed mixer applied at the rate of $4.5 \mathrm{~g} \mathrm{~m}^{-2}$ week ${ }^{-1}$ in treatment $T_{2}$ while no micro and macro nutrients were applied in control.

Table 1. Research design.

\begin{tabular}{|c|c|c|c|}
\hline Parameter/ Stocking Density & Control & Treatment-1 & Treatment-2 \\
\hline Area of each pond & $120-150 \mathrm{~m}^{2}$ & $120-150 \mathrm{~m}^{2}$ & $120-150 \mathrm{~m}^{2}$ \\
\hline Water depth & $1-1.5 \mathrm{~m}$ & $1-1.5 \mathrm{~m}$ & $1-1.5 \mathrm{~m}$ \\
\hline Prawn & $2 / m^{2}$ & $2 / m^{2}$ & $2 / m^{2}$ \\
\hline Rohu & $0.1 / \mathrm{m}^{2}$ & $0.1 / \mathrm{m}^{2}$ & $0.1 / \mathrm{m}^{2}$ \\
\hline Mola & $2 / \mathrm{m}^{2}$ & $2 / \mathrm{m}^{2}$ & $2 / \mathrm{m}^{2}$ \\
\hline Fertilization application & Without fertilizer & $\begin{array}{l}\text { Traditional } \\
\text { inorganic fertilizer }\end{array}$ & $\begin{array}{l}\text { Commercial } \\
\text { inorganic fertilizer }\end{array}$ \\
\hline Dose & No & $\begin{array}{l}\text { Urea 2.45, TSP 2.45, } \\
\text { Molasses-yeast } \\
\text { mixture } 3.09 \\
\text { (g/ m²/ week) }\end{array}$ & $\begin{array}{l}\text { Before stocking: } 2 \\
\mathrm{~kg} / 1000 \mathrm{~m}^{3} \text { of water } \\
\text { During culture } \\
\text { period: } 1 \\
\mathrm{~kg} / 1000 \mathrm{~m}^{3} / \text { week }\end{array}$ \\
\hline Replication & 3 & 3 & 3 \\
\hline
\end{tabular}

Table 2. Composition of micro nutrient enrich fertilizer.

\begin{tabular}{|c|c|}
\hline Type & Composition \\
\hline $\begin{array}{l}\text { Micro nutrient enrich } \\
\text { fertilizer }\end{array}$ & 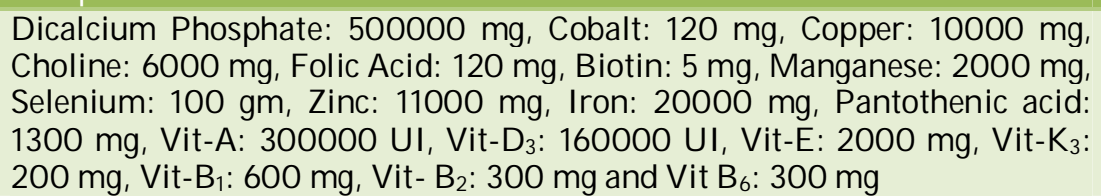 \\
\hline
\end{tabular}




\section{Pre-stocking management}

At the beginning of June, ponds were renovated and cleaned of aquatic vegetation. All unwanted fishes and other aquatic organisms were eradicated by dewatering. Pond dikes were repaired using the excavated bottom soils. The weeds of embankment were also cleaned manually. Surroundings of all ponds were fenced by $1 \mathrm{~m}$ high nylon net to prevent the entry of fishes, snakes and other predators, and escape of prawn. Lime was applied to the pond bottom at the rate of $250 \mathrm{~kg} \mathrm{ha}^{-1}$. The ponds were filled with water after seven days of liming from adjacent deep tube well by using pump. As presented in Table 1, all ponds of treatment 1 were fertilized with inorganic fertilizer like, Urea 2.45, TSP 2.45, Molasses-yeast mixture $3.09\left(\mathrm{~g} \mathrm{~m}^{-2}\right.$ week $\left.{ }^{1}\right)$ and micro nutrients composed mixer (Table 2) applied at a rate of $4.5 \mathrm{~g} \mathrm{~m}^{-2}$ week $^{-1}$ respectively in treatment 2 , while no fertilizers were applied in control. After the first fertilization and before fish stocking, the ponds were left 10 days to allow plankton development.

\section{Stocking}

Stocking in nursery pond

Prawn PL was purchased from a commercial hatchery in Coxes bazar during middle of May 2017 and stocked in nursery pond. While rohu fry and brood mola were purchased from a local seller in Khulna at July 2017.

Stocking in grow-out ponds

Prawn, rohu and mola were stocked in grow out ponds during July 2017. The mean initial weight of prawn, rohu, and mola were 2.32, 94.13 and $2.00 \mathrm{~g}$, respectively in both two treatments and control as well. Before stocking, fish fry and prawn juveniles were conditioned kept in a hapa.

\section{Post stocking management}

All ponds were subject to the same regime of feed and fertilizer application. Feed was provided as farmer regular use in traditional culture system as it is. Fish are fed daily at the rate of $5 \%$ body weight throughout the study period. Half of the required food was applied evenly over the surface of the ponds, in the morning and the rest half in the evening. Fertilization with urea, TSP and molasses-yeast mixture was done at the rate of $2.45,2.45,3.09\left(\mathrm{~g} \mathrm{~m}^{-2}\right.$ week $\left.^{-1}\right)$, respectively at every 7 day interval in $T_{1}$ to keep natural food available in the water and micronutrients composition mixer applied at the rate of $4.5 \mathrm{~g} \mathrm{~m}^{2}$ week $^{-1}$ in treatment-2 While no fertilization is applied in control.
Water sampling and analysis

Water quality parameters like temperature, transparency, DO, pH, alkalinity, hardness, nitrate-nitrogen $\left(\mathrm{NO}_{3}-\mathrm{N}\right)$, nitrite nitrogen $\left(\mathrm{NO}_{2}-\right.$ $\mathrm{N})$, and ammonia-nitrogen $\left(\mathrm{NH}_{3}-\mathrm{N}\right)$ were measured fortnightly. Some of the important analytical methods in some cases with some modification were set up in the Water Chemistry Research Laboratory of Fisheries and Marin Resources Technology (FMRT) Discipline. The water quality parameters like temperature, $\mathrm{pH}$, dissolved oxygen (DO), alkalinity, hardness, ammonia $\left(\mathrm{NH}_{3}\right)$, nitrite, nitrate were analyzed during the whole experiment periods fortnightly.

\section{Growth check}

Five individuals of each species from each treatment are sampled monthly to check the growth and health condition as well as feed adjustment.

The following parameters were used to evaluate the grouth of fishes:

a) Weight gain (gm) = Average final weight (g) average initial weight ( $g$ )

b) Survival rate $(\%)=$ (No of fish harvested/ No of fish stocked) $\times 100$

\section{Harvesting of fish}

Ponds were completely harvested by seine net after six months of rearing. All fishes were counted and weighed separately to assess survival rate and production.

\section{Statistical analysis}

The data collected during experiment were recorded. Data were analyzed using MS excel and the statistical package SPSS (16). One-way ANOVA test was performed to identify any significant differences among treatment means. Significance was assigned at the $5 \%$ level.

\section{Results and Discussion}

\section{Water quality}

Water quality parameters were analyzed to observe any considerable changes that might have occurred in response to different in treatments. Various physical, chemical and biological parameters of pond water were determined under control and two treatments. All parameters were present within the acceptable range for fish culture. Water quality parameters in control and treatments have been presented in Table 3. 
Table 3. Mean ( $\pm \mathrm{SD})$ values and ranges of water quality parameters

\begin{tabular}{|llll|}
\hline Parameters & \multicolumn{3}{l|}{ Experimental groups } \\
\hline \multirow{2}{*}{ Temperature $\left({ }^{\circ} \mathrm{C}\right)$} & $25-31$ & Treatment-2 & Control \\
& $28.50 \pm 2.06^{\mathrm{a}}$ & $25-31$ & $25-31$ \\
\hline $\mathrm{DO}(\mathrm{mg} / \mathrm{l})$ & $6-8$ & $6-8$ & $28.86 \pm 2.30^{\mathrm{a}}$ \\
\cline { 2 - 4 } & $7.09 \pm 0.94^{\mathrm{a}}$ & $7.36 \pm 0.92^{\mathrm{a}}$ & $6-8$ \\
\hline $\mathrm{pH}$ & $7.35-8.70$ & $7.5-8.70$ & $7.54 \pm 0.92^{\mathrm{a}}$ \\
\hline Alkalinity $(\mathrm{mg} / \mathrm{l})$ & $8.32 \pm 0.42^{\mathrm{a}}$ & $8.33 \pm 0.37 \mathrm{a}$ & $8.23 \pm 0.44^{\mathrm{a}}$ \\
& $200-300$ & $200-300$ & $200-275$ \\
\hline Hardness $(\mathrm{mg} / \mathrm{l})$ & $247.73 \pm 32.51^{\mathrm{a}}$ & $245.45 \pm 31.26^{\mathrm{a}}$ & $220.45 \pm 24.54^{\mathrm{a}}$ \\
\hline Nitrite $(\mathrm{mg} / \mathrm{l})$ & $165-200$ & $165-200$ & $155-170$ \\
& $184.55 \pm 11.93^{\mathrm{b}}$ & $183.18 \pm 14.19^{\mathrm{b}}$ & $164.09 \pm 5.39^{\mathrm{a}}$ \\
\hline Nitrate $(\mathrm{mg} / \mathrm{l})$ & $0.0285-0.9715$ & $0.0235-0.1095$ & $0.0235-0.1095$ \\
& $0.08 \pm 0.04^{\mathrm{a}}$ & $0.09 \pm 0.03^{\mathrm{a}}$ & $0.07 \pm 0.03^{\mathrm{a}}$ \\
\hline Ammonia $(\mathrm{mg} / \mathrm{l})$ & $0.130-0.285$ & $0.130-0.285$ & $0.125-0.235$ \\
\hline & $0.21 \pm 0.05^{\mathrm{a}}$ & $0.20 \pm 0.05^{\mathrm{a}}$ & $0.17 \pm 0.03^{\mathrm{a}}$ \\
\hline
\end{tabular}

* Figures in the samerow having the same superscript are not significantly different.

The water temperature, dissolved oxygen (DO) concentration, $\mathrm{pH}$, total alkalinity, hardness, concentration of total ammonia nitrogen $\left(\mathrm{NH}_{3-}\right.$ $\mathrm{N})$, nitrate-nitrogen $\left(\mathrm{NO}_{3}-\mathrm{N}\right)$ and nitrite-nitrogen $\left(\mathrm{NO}_{3}-\mathrm{N}\right)$ of experimental ponds was found to vary from 25 to $31^{\circ} \mathrm{C}, 6$ to $8 \mathrm{mg} \mathrm{L}^{-1}, 7.5$ to $8.7,200-300$ $\mathrm{mg} \mathrm{L}^{-1}, 155-200 \mathrm{mg} \mathrm{L}^{-1}, 0.038$ to $0.138 \mathrm{mg} \mathrm{L}^{-}$ $1,0.125$ to $0.285 \mathrm{mg} \mathrm{L}^{-1}, 0.0235$ to $0.9715 \mathrm{mg} \mathrm{L}^{-1}$ during the experiment in control and two treatments, respectively. No significant difference $(P>0.05)$ was found between control and treatments except hardness. Ahmed (2004), Asaduzzaman (2005), Asaduzzaman et al. (2006), Azim et al. (1995), Dewan et al. (1991), Hoque et al. (2014), Hossain et al. (1997), Kohinoor (2000), Kohinoor et al. (2001), Kohinoor et al. (1998), Kunda et al. (2008), Mazid (2009), Mollah and Haque (1978), Rahman (2005), Roy (2004), and Wahab et al. (1995) also reported similar findings.

\section{Growth and production of fish}

Details of growth and production of Prawn (M. rosenbergii), Rohu (L. rohita) and Mola (A. mola) were presented in Figures 1, 2, 3 and Table 3. Among all species, rohu (L. rohita) attained the maximum weight at harvest while the production of mola had been affected by prawn (M. rosenbergii).

\section{Survival rate}

The survival rates of various species namely prawn (M. rosenbergii) and rohu (L. rohita) in control, treatment- 1 and treatment- 2 were 73.33 , 89.58 and $86.25 \%, 78.00,74.00$ and $74.00 \%$ while mola (A. mola) were 10.67, 15.33 and $15.33 \%$, respectively. Perhaps mola (A. mola) fishes were consumed by prawn (M. rosenbergii). There was no significant difference in the survival rates of prawn (M. rosenbergii), rohu (L. rohita) and mola (A. mola) among control and two treatments.

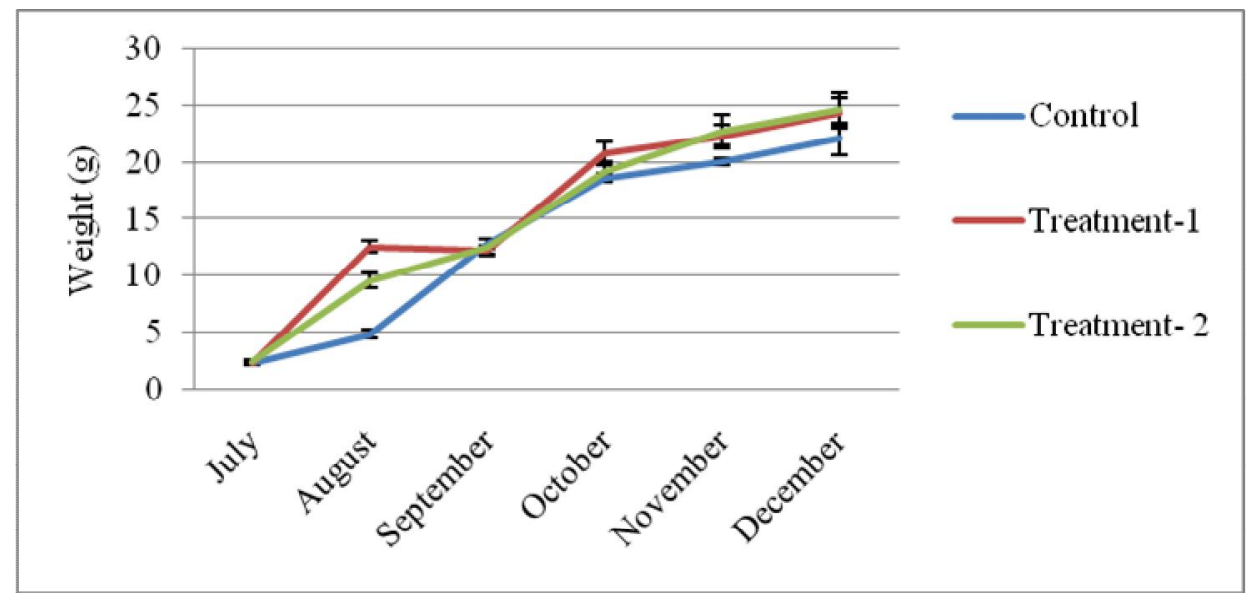

Fig. 1. Growth pattern of Prawn (M. rosenbergii). 


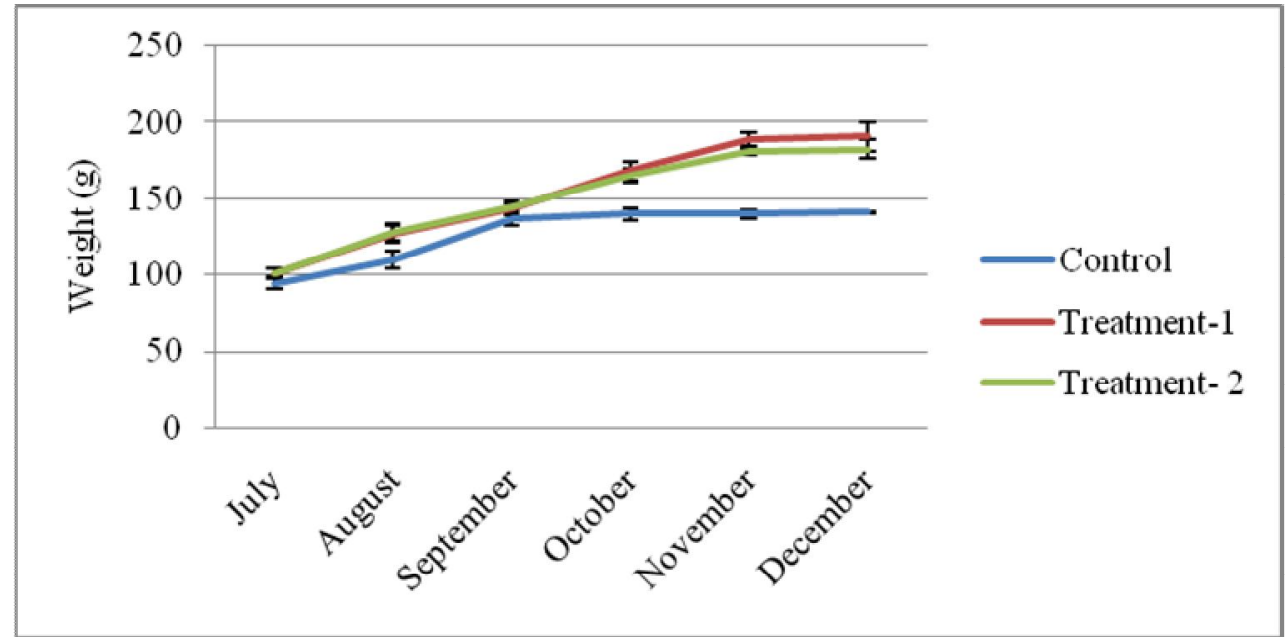

Fig. 2. Growth pattern of Rohu (L. rohita).

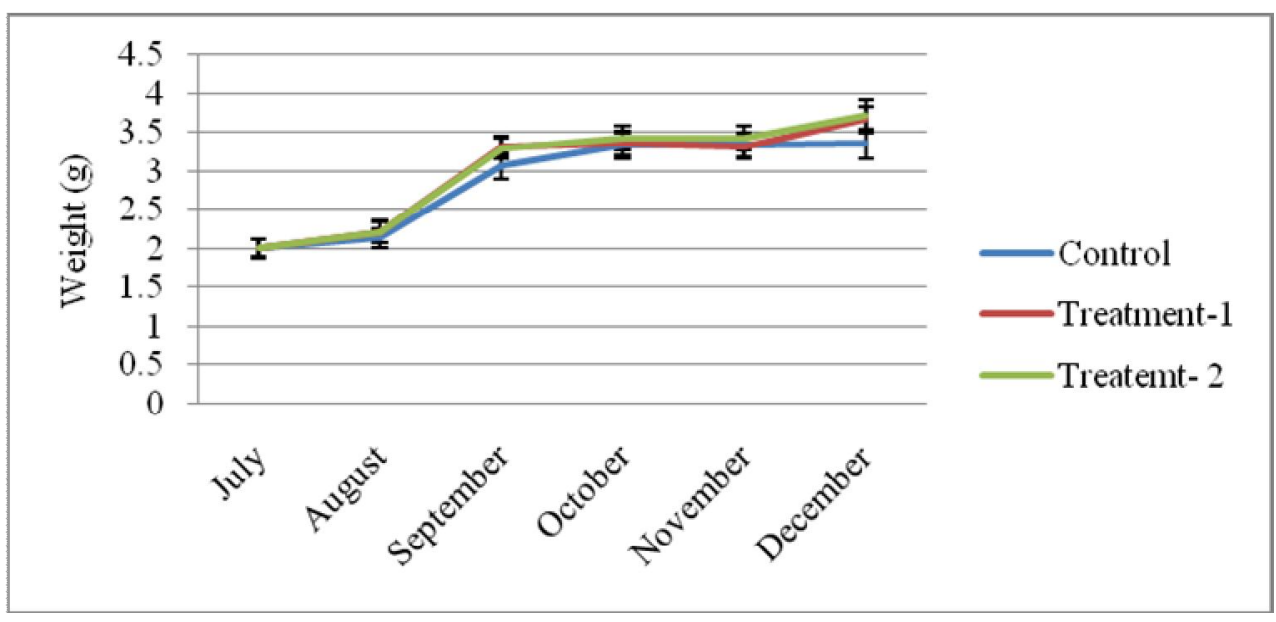

Fig. 3. Growth pattern of Mola (A. mola).

Final Production

The average final mean individual weights of Prawn (M. rosenbergii), Rohu (L. rohita) and Mola (A. mola) in treatment-1 were 24.35, 190.6, $3.67 \mathrm{~g}$ and treatment- 2 were $24.70,182.20,3.73 \mathrm{~g}$ while $22.10,141.10,3.36 \mathrm{~g}$, respectively in control. The final harvest weights of mola (A. mola) in treatment- 1 and treatment- 2 was more or less similar as control. The survival rate of prawn (M. rosenbergii) in treatment-2 was lower than treatment-1. So the final production of treatment1 was more than treatment- 2 but the individual growth of fish species in treatment-2 is more than any other treatments except rohu (L. rohita).

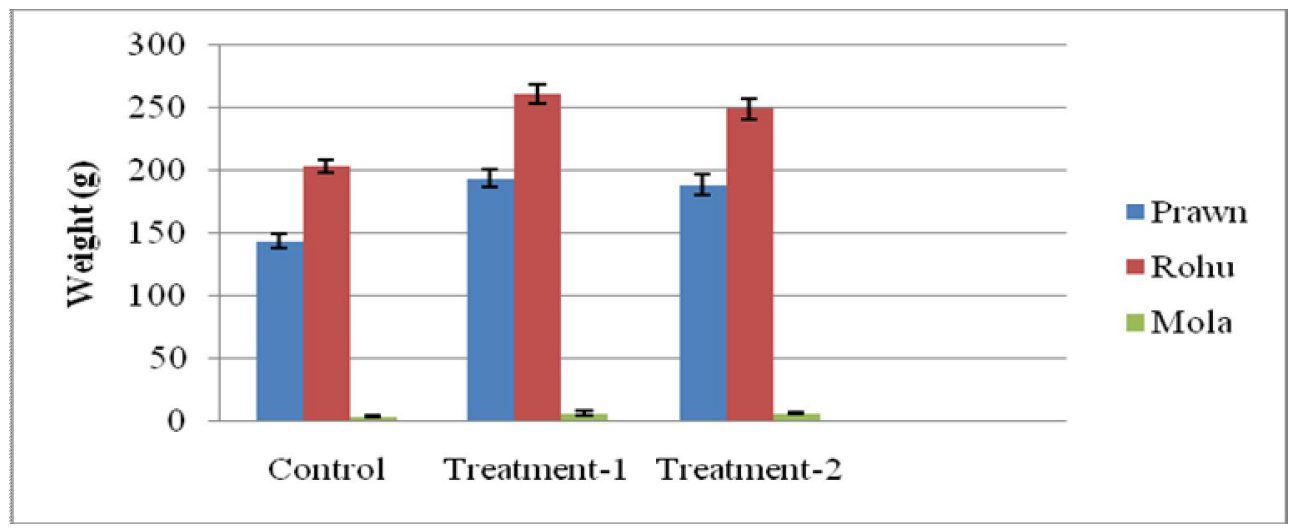

Fig. 4. Total production of prawn, rohu and mola in control and two treatments. 
Production after six months of culture was 351.8, 461.5 and $445.3 \mathrm{~kg} \mathrm{ha}^{-1}$ in control, treatment- 1 and treatment-2, respectively (Table 4). Significant difference was found in the production of Prawn (M. rosenbergii), Rohu (L. rohita) and Mola (A. mola) among control and two treatments. Thilsted (2003) stated that, total fish production was 2560, 2412 and $2176 \mathrm{~kg} \mathrm{ha}^{-1}$ in three treatments, respectively. Though Wahab et al. (2008) mentioned an integrated aquaculture of fresh water prawn (M. rosenbergii) and mola (A. mola) in different plot showed better average production, 222 to $388 \mathrm{~kg} \mathrm{ha}^{-1}, 51$ to $68 \mathrm{~kg} \mathrm{ha}^{-1}$, respectively.

Table 4. Survival and production of prawn, rohu and mola under two treatments.

\begin{tabular}{|c|c|c|c|c|c|c|c|c|c|c|}
\hline \multirow[t]{2}{*}{ Treatment } & \multirow[b]{2}{*}{ Species } & \multicolumn{3}{|c|}{ At stocking } & \multicolumn{3}{|c|}{ At harvest } & \multirow[t]{2}{*}{$\begin{array}{l}\text { Survival } \\
\text { Rate (\%) }\end{array}$} & \multicolumn{2}{|c|}{$\begin{array}{l}\text { Production } \\
\left(\mathrm{kg} \mathrm{ha}^{-1}\right)\end{array}$} \\
\hline & & $\begin{array}{l}\text { Av. } \\
\text { Initial } \\
\text { wt (g) }\end{array}$ & $\begin{array}{l}\text { No. of } \\
\text { fish } \\
\text { stocke } \\
\text { d }\end{array}$ & $\begin{array}{l}\text { Total } \\
\text { ut (g) }\end{array}$ & $\begin{array}{c}\text { Av. } \\
\text { Final ut } \\
\text { (g) }\end{array}$ & $\begin{array}{l}\text { No of fish } \\
\text { recovered }\end{array}$ & $\begin{array}{l}\text { Total wt } \\
\text { (g) }\end{array}$ & & $\begin{array}{l}\text { Species } \\
\text { wise }\end{array}$ & Total \\
\hline \multirow[t]{3}{*}{ Control } & Prawn & 2.32 & 240 & 556.8 & 22.10 & 176 & 3889.60 & 73.33 & 144.0 & \multirow{3}{*}{351.8} \\
\hline & Rohu & 94.13 & 50 & 4706.5 & 141.10 & 39 & 5502.90 & 78.00 & 203.8 & \\
\hline & Mola & 2.00 & 300 & 600.0 & 3.36 & 32 & 107.52 & 10.67 & 4.0 & \\
\hline \multirow[t]{3}{*}{ Treatment-1 } & Prawn & 2.32 & 240 & 556.8 & 24.35 & 215 & 5235.25 & 89.58 & 194.0 & \multirow{3}{*}{461.5} \\
\hline & Rohu & 100.30 & 50 & 5015.0 & 190.60 & 37 & 7052.20 & 74.00 & 261.2 & \\
\hline & Mola & 2.00 & 300 & 600.0 & 3.67 & 46 & 168.82 & 15.33 & 6.3 & \\
\hline \multirow[t]{3}{*}{ Treatment-2 } & Prawn & 2.44 & 240 & 585.6 & 24.70 & 207 & 5112.90 & 86.25 & 189.3 & \multirow{3}{*}{445.3} \\
\hline & Rohu & 100.85 & 50 & 5042.5 & 182.20 & 37 & 6741.40 & 74.00 & 249.6 & \\
\hline & Mola & 2.00 & 300 & 600.0 & 3.73 & 46 & 171.58 & 15.33 & 6.4 & \\
\hline
\end{tabular}

In conclusion, fertilizer indirectly took part major role in the production of mola and rohu through increasing plankton production. Additionally, mola probably ensured better production of prawn through consumption as prawn is a carnivorous species in nature. While Rohu- mola culture technology could be a good proposition as a rural aquaculture technology in terms of nutrition and socio-economic aspects. However, it could be concluded that including mola could to maximize the production of prawn as well as rohu in fertilizer included polyculture system though we have to sacrifice mola production. In view of the above, it may be recommended that though the production of mola was not encouraging in fertilizer based prawn, rohu, mola monoculture system but it might be very encouraging with carp included polyculture system to meet the demand of nutritional benefit for rural people specially women and children.

\section{Acknowledgements}

The authors are grateful to the Khulna University Research Cell for financial support.

\section{References}

Ahmed, Z.F. 2004. Electivity index and dietary overlap of Catla catla (Hamilton) in fertilized ponds of Bangladesh. M.S. Dissertation, Department of Fisheries Biology and Limnology, Bangladesh Agricultural University, Mymensingh. 163p.

Asaduzzaman, M. 2005. The potentials of organic farming of giant freshwater prawn (Macrobrachium rosenbergii) in Bangladesh. M.S. Dissertation, Department of Fisheries Management, Bangladesh Agricultural University, Mymensingh. 125p.

Asaduzzaman, M., Yang, Y., Wahab, M.A., Diana, J.S. and Ahmed, Z.F. 2006. Farming system of giant freshwater prawn (Macrobrachium rosenbergii) in Bangladesh: a combination of tradition and technology. pp. 187-194. In: Proceeding of the WAS conference held on 9-13 May, 2006 in Florence, Italy.

Azim, M.E., Talukder, G.S., Wahab, M.A., Haque, M.M. and Haq, M.S. 1995. Effect of liming and maintenance of total hardness levels on fish production in fertilized ponds. J. Agril. Prog. 6(2): 7-14.

Boyd, C.E. 1976. Nitrogen fertilizer effects on production of Tilapia in ponds fertilized with phosphorus and potassium. Aqua. 7(4): 385390.

Boyd, C.E. 1982. Water quality management for pond fish culture. Elsevier Scientific Pub. Co. $318 \mathrm{p}$.

Chakrabarty, R.D., Murty, D.S., Sen, P.K., Nandy A.C. and Chakrabarty, D.P. 1976. Short- term rearing of lndian and exotic carps. J. Inland Fish. Soc. India. 8: 179-183.

Debeljak, L., Turk, M., Fasaic, K. and Popovic, J. 1990. Mineral fertilizers and fish production in carp ponds. pp. 187-193. In: Berka, R. and Hilge, V. eds. Proceedings of the FAO-EIFAC Symposium on Production Enhancement in Still Water Pond Culture. Research Institute of Fish Culture and Hydrobiology, Vodnany, Czechoslovakia.

Dewan, D., Wahab, M.A., Beveridge, M.C.M., Rahman, M.H. and Sarkar, B.K. 1991. Food selection, electivity and dietary overlap among planktivorous Chinese and Indian major carp fry and fingerlings grown in extensively managed, rain-fed ponds in Bangladesh. Aqua. Res. 22(3): 277-294.

FAO. 2016. The State of World Fisheries and Aquaculture. FAO Publication, Rome, Italy.

Garg, S.K. and Bhatnagar, A. 1999. Effect of different doses of organic fertilizer (cow dung) on pond productivity and fish biomass 
in still water ponds. J. Appl. Ichthyol. 15(1): 10-18.

Green, B.W., Phelps, R.P. and Alvarenga, H.R. 1989. The effect of manures and chemical fertilizers on the production of Oreochromis niloticus in earthen ponds. Aqua. 76(1-2): 37-42.

Green, E.P., Harris, R.P. and Duncan, A. 1992. The production and ingestion of faecal pellets by nauplii of marine calanoid copepods. J. Plankton Res. 14(12): 16311643.

Harris, G.P. 1986. Phytoplankton Ecology, Structure, Function and Fluctuation Chapman and Hall, London, U.K. 260 p.

Hassler, C.S., Sinoir M., Clementson, L.A. and Butler E.C.V. 2012. Exploring the link between micronutrients and phytoplankton in the Southern Ocean during the 2007 austral summer. Front. Microbiol. 3: 1-26.

Hoq, M.E., Islam, M.M. and Hossain, M.M. 1996. Polyculture of freshwater prawn (Macrobrachium rosenbergii) with Chinese and Indian carps in farmer's pond. J. Aqua. Tropics. 11: 135-142.

Hoque, M.M., Motin, M.A., Maya, M., Uddin, M. R. and Chowdhury, A.J.K. 2014. Water Quality and Plankton Composition of Amblypharyngodon mola Monoculture Fish Pond in Bangladesh. Int. J. Emerging Trends Sci. Tech. 1(7): 1005-1014

Hossain, M.A., Rahmatullah, S.M., Islam, M.S., Kabir, A.K.M.A., Islam, M.S. and Dewan, S. 1997. Impact of chapila (Gudusia chapra Ham.) on growth of carps in polyculture. Bangladesh J. Fish. Res. 1(2): 19-23.

Kohinoor, A.H.M. 2000. Development of culture technology of three small indigenous fish mola (Amblypharyngodon mola), punti (Puntius sophore) and chela (Chela cachius) with notes on some aspects of their biology. A $\mathrm{PhD}$ dissertation, Department of Fisheries Management, Bangladesh Agricultural University, Mynensingh, 365p.

Kohinoor, A.H.M., Islam, M.L., Wahab, M.A. and Thirsted, S.H. 1998. Effect of mola (Amblypharyngodon mola Ham.) on the growth and production of carps in polyculture. Bangladesh J. Fish. Res. 2(2): 119-126.

Kohinoor, A.H.M., Wahab, M.A., Islam, M. and Thilsted, S.H. 2001. Culture potentials of mola (Amblypharyngodon mola), chela (Chela cachius) and punti (Puntius sophore) under monoculture system. Bangladesh J. Fish. Res. 5(2): 123-134.

Kunda, M., Azim, M.E., Wahab, M.A., Dewan, S., Roos, N. and Thilsted, S.H. 2008. Potential of mixed culture of freshwater prawn (Macrobrachium rosenbergii) and self-recruiting small species mola (Amblypharyngodon mola) in rotational rice-fish/prawn culture systems in Bangladesh. Aqua. Res. 39(5): 506-517.

Mazid, M.A. 2009. Training manual on water quality management in shrimp farm Bangladesh Quality Support ProgrammFisheries, UNIDO, DHAKA, Bangladesh. $108 p$.

Mollah, M.F.A. and Haque, A.K.M.A. 1978. Studies on monthly variation of plankton in relation of the physio-chemical conditions of water and bottom soil of two ponds. I. Phytoplankton. Bangladesh J. Fish. 1: 29-39.

Moses, B.S. 1983. Introduction to tropical fisheries, studies in the biology of Africa Ibadan University Press. 117p.

Pearson, T.R., Takahashi, M. and Hargrare, B. 1984. Biological oceanographic $3^{\text {rd }}$ edition. Oxford: Pergamon Press. 380p.

Rahman, M.A. 2005. Production performance of overwintering juveniles of giant freshwater prawn, Macrobrachium rosenbergii under monosex and mixed sex culture systems. M.S. Dissertation, Dept. of Fisheries Management, Bangladesh Agricultural University, Mymensingh. 95p.

Roy, N.C. 2004. Effects of Carp-SIS Polyculture System on Pond Fish Production, Nutritional Security and Socioeconomic Benefit of the Rural People. Ph.D. Dissertation, Department of Fisheries Management, Bangladesh Agricultural University, Mymensingh. 184p.

Thilsted, S.H. 2003. The importance of small indigenous fish species for improved human nutrition in rural Bangladesh. In: M.A. Wahab, S.H. Thilsted, M.E. Hoq, eds. Small indigenous species of fish in Bangladesh. Technical Proceedings of BAUENRECA/DANIDA Workshop on Potentials of Small Indigenous Species of Fish (SIS) in Aquaculture and Rice-field Stocking for Improved Food and Nutrition Security in Bangladesh. Mymensingh, Bangladesh, Bangladesh Agricultural University.

Wahab, M.A., Ahmed, Z.F., Haq, M.S. and Begum, M. 1994. Compatibility of silver carp in the poly culture of cyprinid fishes. Prog. Agric. 5 (2): 221-227.

Wahab, M.A., Ahmed, ZF., Islam, M.A., Haq, M.S. and Rahmatullah, S.M. 1995. Effects of introduction of common carp, Cyprinus carpio (L.), on the pond ecology and growth of fish in polyculture. Aqua. Res. 26(9): 619628.

Wahab, M.A., Kunda, M., Azim, M.E., Dewan, S. and Thilsted, S.H. 2008. Evaluation of freshwater prawn- small fish culture in rainfed rice-fields in Bangladesh. Aqua. Res. 39: 1524- 1532.

Westly, R.R. 1984. Fish Pond Management, National Integrated Fisheries Technology Development Center. pp. 27-41. http://aquatechnidocwestly.weebly.com/uploads L1/0/6/3/10636182/fishpond management.pdf. 